\title{
SPECTROPHOTOMETRIC DETERMINATION OF PRASEODYMIUM, NEODYMIUM, AND SAMARIUM
}

\author{
By Clement J. Rodden
}

\section{ABSTRACT}

Praseodymium, neodymium, and samarium, in nitrate solutions, have been determined by measuring the transmittancies of the solutions with a doublemonochromator photoelectric spectrophotometer.

Spectral transmittancy curves from 350 to $1,000 \mathrm{~m} \mu$ were obtained for lanthanum, cerium, praseodymium, neodymium, samarium, europium, and gadolinium. The absorption band found to be most suitable for the determination of praseodymium was at $446 \mathrm{~m} \mu$; for neodymium, the bands at 521 and $798 \mathrm{~m} \mu$; and for samarium, $402 \mathrm{~m} \mu$. Lanthanum, cerium, and gadolinium show negligible absorption between 400 and $1,000 \mathrm{~m} \mu$. Europium shows a small absorption band at $396 \mathrm{~m} \mu$.

Transmittancy-concentration curves were obtained for the individual elements in concentrations ranging from 0.25 to $25 \mathrm{mg} / \mathrm{ml}$. These curves show that for concentrations up to $10 \mathrm{mg} / \mathrm{ml}$, solutions of neodymium follow Beer's law, while in concentrations greater than $10 \mathrm{mg} / \mathrm{ml}$ this law does not hold. Praseodymium and samarium solutions do not follow Beer's law under the conditions used.

Approximately $1 \mathrm{mg}$ of praseodymium per $6 \mathrm{ml}$ can be detected. The sensitivity of the neodymium test depends on the band used; $1.5 \mathrm{mg}$ can be detected by using the $521 \mathrm{~m} \mu$ band and $0.5 \mathrm{mg}$ by using the $798 \mathrm{~m} \mu$ band. The test for samarium is less sensitive than for the other two elements, $3 \mathrm{mg}$ being the minimum detected.

Mixtures of the three elements were analyzed and also mixtures of each of the three elements with lanthanum. The mixtures varied from one containing 5.0 $\mathrm{mg}$ of neodymium and $200 \mathrm{mg}$ of lanthanum, to one consisting of $75 \mathrm{mg}$ of samarium, $75 \mathrm{mg}$ of praseodymium, and $50 \mathrm{mg}$ of neodymium. A weight of mixed oxides corresponding to approximately $200 \mathrm{mg}$ of rare earth elements was used for each analysis. The accuracy obtained was of the order of $\pm 3 \mathrm{mg}$.

A method is given for correcting the slight interference of each element in a mixture, and a procedure is outlined for the analysis of a mixture of the cerium group of elements obtained during the course of a mineral analysis.

\section{CONTENTS}

I. Introduction

II. Experimental

1. Apparatus _.

2. Materials

3. Transmittancy measurements _. _

1II. Results obtained

IV. Discussion .....

\section{INTRODUCTION}

The term "rare earth metals" is used to designate the elements cerium, praseodymium, neodymium, 61, samarium, europium, gadolinium, terbium, dysprosium, holmium, erbium, thulium, ytterbium, 
and lutecium, which have the atomic numbers 58 to 71 , and which are usually grouped with lanthanum in the periodic table. In most analytical work, however, scandium (at. No. 21), yttrium (at. No. 39), lanthanum (at. No. 57), and sometimes thorium (at. No. 90) are included with the rare earth metals, because they resemble the rare earths in many of their properties.

Because the rare earths are very similar in their chemical and their physical properties, the means of separating them are very limited. The analyst can separate scandium, cerium, and thorium from the others in the group. He can make use of the relative insolubility of the double alkali sulfates of lanthanum, cerium, praseodymium, neodymium, samarium, europium, and gadolinium in a saturated solution of potassium or sodium sulfate to separate these elements (the cerium group) from the remainder (the yttrium group). ${ }^{1}$ In this way it is possible to obtain elements near the extreme ends of the solubility series free from one another, but the division between the groups is not sharp.

The salts of most of the rare earth metals are colored and their solutions show characteristic sharp absorption bands in the visible and ultraviolet region of the spectrum. ${ }^{2}$ The possibility of using these absorption bands as a means of determining the respective elements in mixtures has been recognized for a considerable time. Four different methods have been used for the estimation of the rare earths by means of their absorption spectra. In the oldest method, which is based on the Nessler principle, the test solution is diluted until, with a direct-vision spectroscope, the absorption intensities of suitable bands appear to equal those of a standard solution placed in juxtaposition. ${ }^{3}$ This method has been used chiefly to determine impurities in so-called pure salts of the rare earths. Friend and Hall ${ }^{4}$ used a modification of this method and stated that, "Whilst it is apparently impossible to determine directly with an approach to accuracy the amount of praseodymium nitrate in the presence of neodymium nitrate, the latter can readily be estimated in presence of up to $50 \%$ of the former in $4 \%$ solution."

The second method is based on finding the dilution necessary for the disappearance of characteristic absorption bands. Haas ${ }^{5}$ determined the concentration of neodymium and of praseodymium in mixtures from the absorption spectra of the nitrates, by diluting the solutions until the neodymium band at $521 \mathrm{~m} \mu$ (green region) could no longer be seen. The band at $480 \mathrm{~m} \mu$ (violet region) was used for the determination of praseodymium. It was found that lanthanum did not interfere. Schumacher ${ }^{6}$ determined praseodymium and neodymium in a samarium preparation by the same method. Yntema ${ }^{7}$ suggested photographic recording in a similar method.

The third method is that of Delauney, ${ }^{8}$ who plotted curves to show the relationship between the widths of the chief absorption bands in the visible spectrum and the lengths of the absorption tube. The widths of the bands obtained with solutions of known composition were compared with those of unknown composition, and on the

${ }^{1}$ W. F. Hillebrand and G. E. F. Lundell, Applied Inorganic Analysis, p. 437 (John Wiley \& Sons, New York, N. Y., 1929).

${ }_{2}$ W. Prandtl and K. Scheiner, Z. anorg. allgem. Chem. 220, 107 (1934).

3 B. Brauner, Chem. News $\boldsymbol{\gamma} \%, 161$ (1898).

4 J. N. Friend and D. A. Hall, Analyst 65, 144 (1940).

Haas, Beitr. Kenntnis Pru. Nd. Dissert. Berlin 47, 51, 54 (1920).

- G. Schumacher, Z. Kenntnis Samarium. Dissert. Berlin 14 (1921).

7 L. F. Yntema, J. Am. Chem. Soc. 45, 907 (1923).

E. Delauney, Compt. rend. 185, 354 (1927). 
assumption that Beer's law applies, the concentrations of the salts giving bands of equal width were calculated from the inverse ratio of the lengths of the absorption tube. A photographic method of recording was used.

The fourth method is based on the use of the spectrophotometer and was used initially by Muthrnann and Stützel. ${ }^{9}$ Praseodymium and neodymium in mixtures were determined by using a visual spectrophotometer. The band at $521 \mathrm{~m} \mu$ was employed for neodymium and the one at $480 \mathrm{~m} \mu$ for praseodymium. The band at 480 $\mathrm{m} \mu$, however, is materially affected by neodymium and samarium, and therefore the results are somewhat in error. Partridge and Rodden ${ }^{10}$ used filters of colored glass and gelatin to isolate certain bands corresponding to the absorption regions of neodymium, praseodymium, and samarium. A photoelectric means of recording was used. Though neodymium could be determined in mixtures of praseodymium and neodymium, the determinations of praseodymium and samarium in mixtures were not satisfactory. O. S. Plantinga ${ }^{11}$ showed that neodymium could be determined in a mixture of praseodymium and neodymium by using a filter photometer with a photronic cell as the measuring device. In this procedure, $0.015 \mathrm{~g}$ of neodymium could be detected, and the deviation from the true value in most cases was of the order of 1 percent in equimolar mixtures containing up to 0.24 mole per liter of each ion. The measurements were affected by salts other than those of rare earths, and by the acidity.

In preliminary experiments in this laboratory with a filter photometer, ${ }^{12}$ an attempt was made to isolate certain narrow bands by using solutions of rare earth salts as well as glasses containing rare earth oxides. The results were unsatisfactory and indicated the necessity of using some type of spectrophotometer. In the work reported in the present paper a spectrophotometer ${ }^{13}$ was used to determine spectral transmittancy curves of lanthanum, cerium, praseodymium, neodymium, samarium, europium, and gadolinium. Transmittancy-concentration curves for praseodymium, neodymium, and samarium were obtained. From these measurements it was possible to determine praseodymium, neodymium and samarium in mixtures of the three, together with lanthanum. Similar measurements have been made on the yttrium group of elements, and the results will be reported in a subsequent publication.

\section{EXPERIMENTAL}

\section{APPARATUS}

A Coleman double-monochromator spectrophotometer, model $10 \mathrm{~S}$ was used, equipped with a slit stated by the manufacturer to select a spectral region of $5 \mathrm{~m} \mu$. In this instrument the source of radiant energy is a line-coiled filament energized by a 4-cell lead storage

\footnotetext{
W. Muthmann and L. Stützel, Ber. deut. chem. Ges. 32, 2653 (1899).

$10 \mathrm{H}$. M. Partridge and C. J. Rodden. Abstracts of the Indianapolis meeting of the American Chemical

Society, (March 1931). University (1934).

12 B. A. Brice, Rev. Sci. Instr. 8, 279 (1937)

13 The cost of a spectrophotometer has, prior to the recent introduction of certain moderately priced photoelectric spectrophotometers, generally precluded its use in the analytical laboratory.
} 
battery of high capacity. The source remains substantially constant during the time required for the desired test. The radiant energy passes first through a diffraction grating attached to a condensing lens and next through a slit. The nearly homogeneous energy from that slit passes through a right-angled prism to which is attached a second diffraction grating which disperses the stray energy. A narrow exit slit then isolates the $5-\mathrm{m} \mu$ band of energy used in the measurements. This band can be selected anywhere in the range from 350 to $1,000 \mathrm{~m} \mu$. The homogeneous energy then passes through the absorption cell to a cesium oxide photocell. Absorption cells of two types were used: (1) Cylindrical cells of approximately $17 \mathrm{~mm}$ internal diameter which required 8 to $10 \mathrm{ml}$ of solution; and (2) square cells with $13.08 \mathrm{~mm}$ between faces which required 5 to $6 \mathrm{ml}$ of solution. $B$ batteries supply the potential for the photocell. A dark current compensator is built into the spectrophotometer. A Coleman electrometer, type $3 \mathrm{E}$, was used in conjunction with the spectrophotometer to measure the transmittancy $(\mathbf{T})^{14}$ of the solution.

The wavelength scale of the instrument was calibrated from 400 to $750 \mathrm{~m} \mu$, by means of rare earth glasses. ${ }^{15}$

\section{MATERIALS}

Lanthanum.-The lanthanum oxide was of unknown origin. Its emission spectrum ${ }^{16}$ showed arsenic, in the order of 0.1 percent, as well as barium, calcium, and magnesium in the order of 0.01 percent. No other rare earth was detected. After ignition of the oxide at $1,100^{\circ} \mathrm{C}$, an amount equivalent to $2.5 \mathrm{~g}$ of lanthanum was dissolved in nitric acid, the solution was evaporated to dryness on the steam bath, and the residue was dissolved in water and diluted to $100 \mathrm{ml}$ in a volumetric flask. Other solutions of lanthanum were prepared from this solution by diluting with water.

Cerium.-The cerium nitrate used was prepared from the oxide obtained from one of the supply houses. The oxide contained 1.7 percent of impurities, which were chiefly thorium, chromium, and aluminum. No rare earths were detected. The cerium oxide was converted to sulfate, precipitated with ammonia, and, after washing, was dissolved in nitric acid. Water was then added and the solution evaporated to dryness and made up to $0.0231 \mathrm{~g}$ of cerium per milliliter with water.

Praseodymium.-The praseodymium oxide was obtained from the Charles James collection. Its emission spectrum showed faint traces of calcium, iron, magnesium, and silicon. The amount of lanthanum was estimated to be less than 1.0 percent and that of yttrium and cerium less than 0.01 percent each. No other rare earths were detected. The praseodymium oxide was ignited at $900^{\circ} \mathrm{C}$, and an amount necessary to give $2.5 \mathrm{~g}$ of praseodymium, on the basis of $\operatorname{Pr}_{6} \mathrm{O}_{11}{ }^{17}$ was dissolved in nitric acid and treated like the lanthanum preparation.

14 The transmittancy is defined as the ratio of the transmission of a cell containing solution to that of an identical cell containing distilled water.

$1 s$ Acknowledgment is made to H. J. Keegan, of the Photometry and Colorimetry Section of this Bureau, for the transmission measurements of these glasses, made on the General Electric recording spectrophotometer.

${ }_{16}$ Acknowledgment is made to B. F. Scribner and H. R. Mullin, of this Bureau, for emission-spectrum analyses of the salts used.

17 P. H. M-P. Brinton and H. A. Pagel, J. Am. Chem. Soc. 45, 1460 (1923). 
Neodymium.-The neodymium material was purified by the author by crystallization of the double magnesium nitrate. The emission spectrum of the oxide showed less than 0.01 percent each of calcium, magnesium, and silicon. No other rare earth was detected. A solution containing $0.025 \mathrm{~g}$ of neodymium per milliliter was prepared in the way described under lanthanum.

Samarium.-The samarium oxide was obtained from the Charles James collection and showed calcium, iron, magnesium, and silicon in amounts less than 0.01 percent each. Europium was present, but in amount less than 0.01 percent. A solution of $0.025 \mathrm{~g}$ of samarium per milliliter was prepared as described for lanthanum.

Europium.-The europium oxide was obtained from the Charles James collection. Its emission spectrum showed the presence of gadolinium and samarium in the order of 0.1 percent each. A solution containing $0.0182 \mathrm{~g}$ of europium per milliliter was prepared in the way described under lanthanum.

Gadolinium.-The gadolinium oxide was obtained from the Charles James collection. Its emission spectrum showed the presence of europium as a major constituent. No other rare earths were detected. A solution containing $0.025 \mathrm{~g}$ of gadolinium $(\mathrm{Gd}+\mathrm{Eu})$ per milliliter was prepared in the way described under lanthanum.

From these master solutions, mixtures which contained different amounts of the several elements were prepared.

\section{TRANSMITTANCY MEASUREMENTS}

Spectral transmittancy $(S T)$ curves for lanthanum, cerium, praseodymium, neodymium, samarium, europium, and gadolinium nitrate

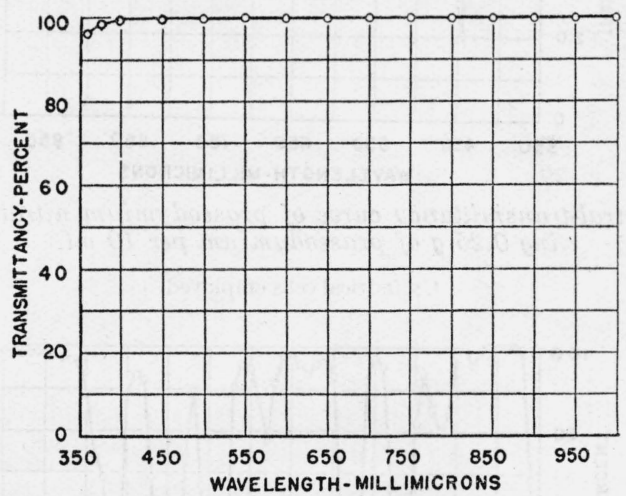

FIGURE 1.-Spectral-transmittancy curve of lanthanum nitrate solution containing $0.25 \mathrm{~g}$ of lanthanum per $10 \mathrm{ml}$.

Cylindrical cells employed.

solutions are shown in figures $1,2,3,4,5,6$, and 7 . For all but lanthanum, cerium, and gadolinium, readings were made at intervals of $10 \mathrm{~m} \mu$, except where intense absorption bands occurred, in which case $1-$ to $2-\mathrm{m} \mu$ steps were used in order to obtain the transmittancy and wavelength at minimum transmittancy. Readings obtained for lanthanum, cerium, and gadolinium were made at the wavelengths indicated in the figures. The $S T$ curve for a mixture of praseodymium, neodymium, and samarium is shown in figure 8 . 


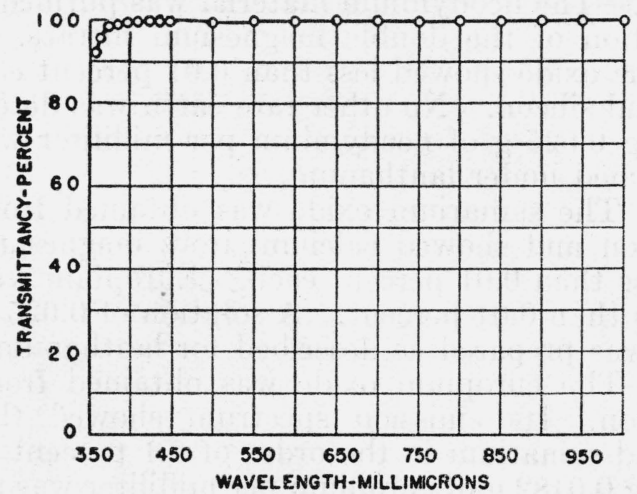

FIGURE 2.-Spectral-transmittancy curve of cerium nitrate solution containing 0.231 $g$ of cerium per $10 \mathrm{ml}$.

Square cells employed.

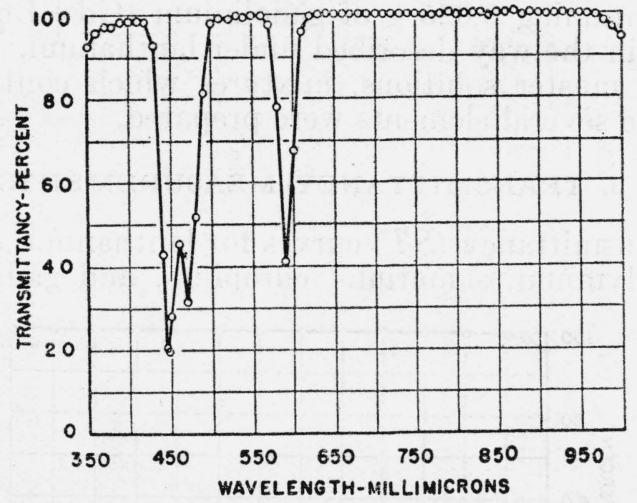

FiguRe 3.-Spectral-transmittancy curve of praseodymium nitrate solution containing $0.25 \mathrm{~g}$ of praseodymium per $10 \mathrm{ml}$.

Cylindrical cells employed.

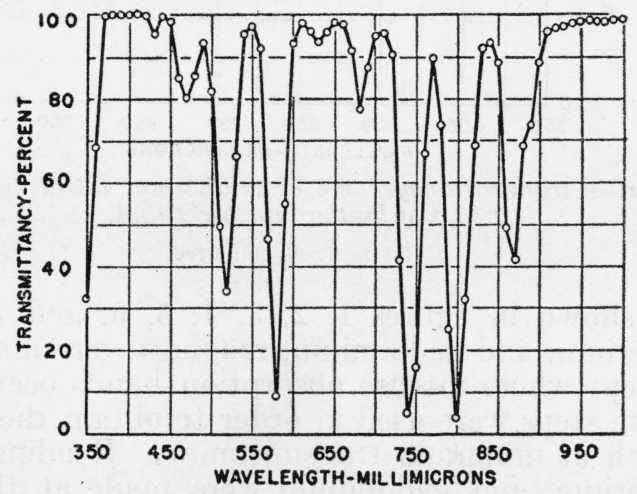

FIGURE 4.-Spectral-transmittancy curve of neodymium nitrate solution containing $0.25 \mathrm{~g}$ of neodymium per $10 \mathrm{ml}$.

Cylindrical cells employed. 


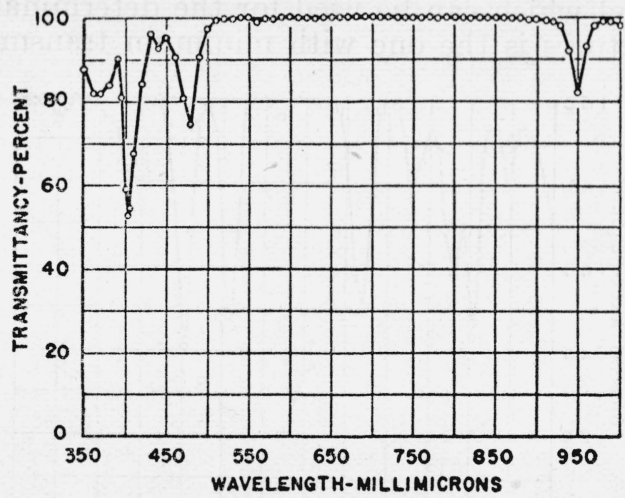

FIGURE 5.-Spectral-transmittancy curve of samarium nitrate solution containing $0.25 \mathrm{~g}$ of samarium per $10 \mathrm{ml}$.

Cylindrical cells employed.

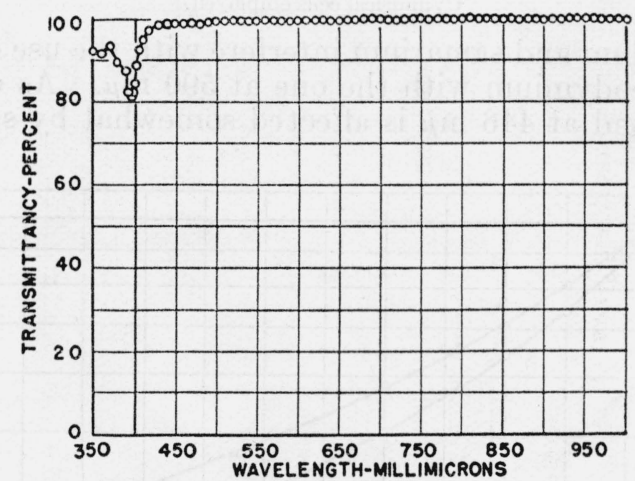

FIGURE 6.-Spectral-transmittancy curve of europium nitrate solution containing $0.182 \mathrm{~g}$ of europium per $10 \mathrm{ml}$.

Square cells employed.

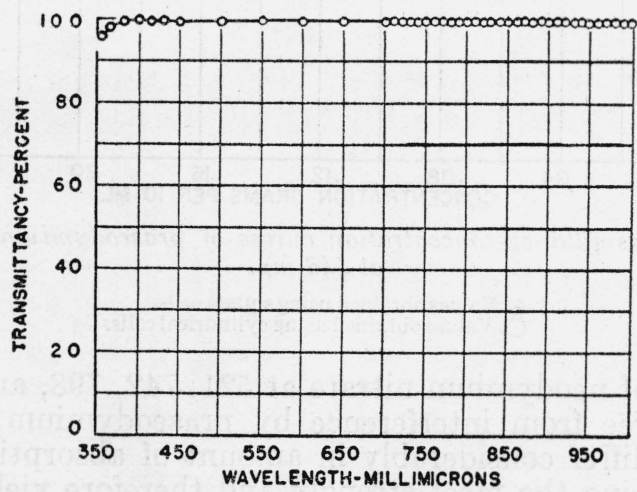

FIGURE 7.-Spectral-transmittancy curve of gadolinium nitrate solution containing $0.25 \mathrm{~g}$ of gadolinium per $10 \mathrm{ml}$.

Square cells employed. 
The only band which can be used for the determination of praseodymium in mixtures is the one with minimum transmittancy at 446

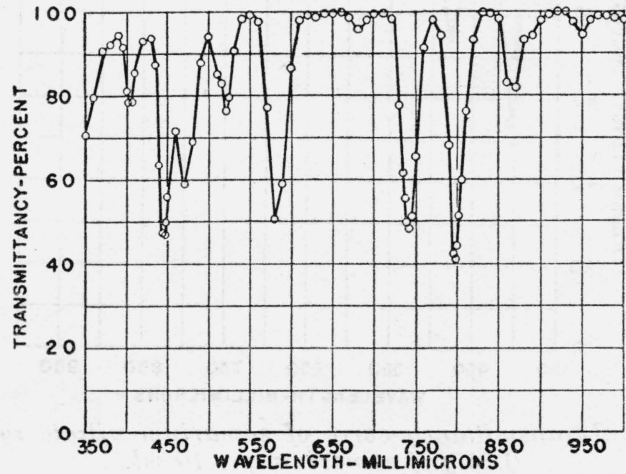

FIGURE 8.-Spectral-transmittancy curve of a nitrate solution containing $0.050 \mathrm{~g}$ of neodymium, $0.075 \mathrm{~g}$ of praseodymium, and $0.075 \mathrm{~g}$ of samarium per $10 \mathrm{ml}$.

Cylindrical cells employed.

$\mathrm{m} \mu$, as neodymium and samarium interfere with the use of the band at $469 \mathrm{~m} \mu$, and neodymium with the one at $590 \mathrm{~m} \mu$. As can be seen in figure 5 , the band at $446 \mathrm{~m} \mu$ is affected somewhat by samarium.

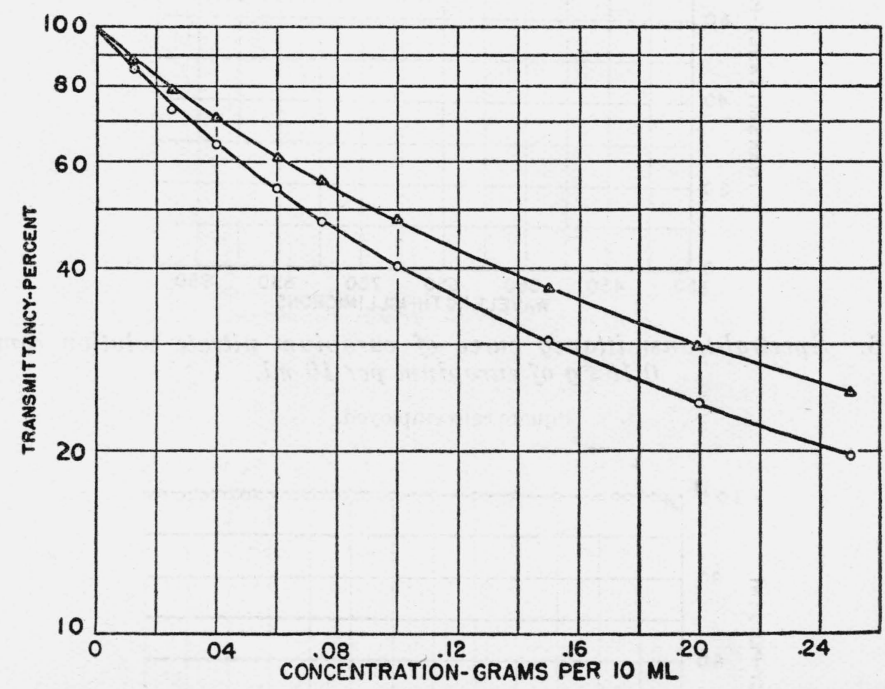

FIGURE 9.-Transmittancy-concentration curves of praseodymium nitrate solutions at $446 \mathrm{m \mu}$.

$\triangle$, Values obtained using square cells.

$\widehat{O}$, Values obtained using cylindrical cells.

The bands of neodymium nitrate at $521,742,798$, and $870 \mathrm{~m} \mu$ are, fortunately, free from interference by praseodymium or samarium. These bands differ considerably in amount of absorption, the one at $798 \mathrm{~m} \mu$ absorbing the most strongly and therefore yielding the most sensitive test procedure. 
The absorption band of samarium nitrate at $402 \mathrm{~m} \mu$ is the only one which can be used for this element, because the absorption at $949 \mathrm{~m} \mu$ is rather low and praseodymium and neodymium interfere at $479 \mathrm{~m} \mu$. The bands of samarium show less absorption than the other elements of the cerium group except europium, hence, samarium can be determined less precisely than neodymium and praseodymium.

Transmittancy-concentration curves for praseodymium, neodymium, and samarium were obtained with both square and cylindrical cells.

The transmittancies of praseodymium nitrate solutions were obtained at 402,446 , and $521 \mathrm{~m} \mu$, at concentrations ranging from 0.0125 to $0.25 \mathrm{~g}$ of praseodymium per $10 \mathrm{ml}$. (This material may have as high as 1 percent of lanthanum.) The results for the band at 446

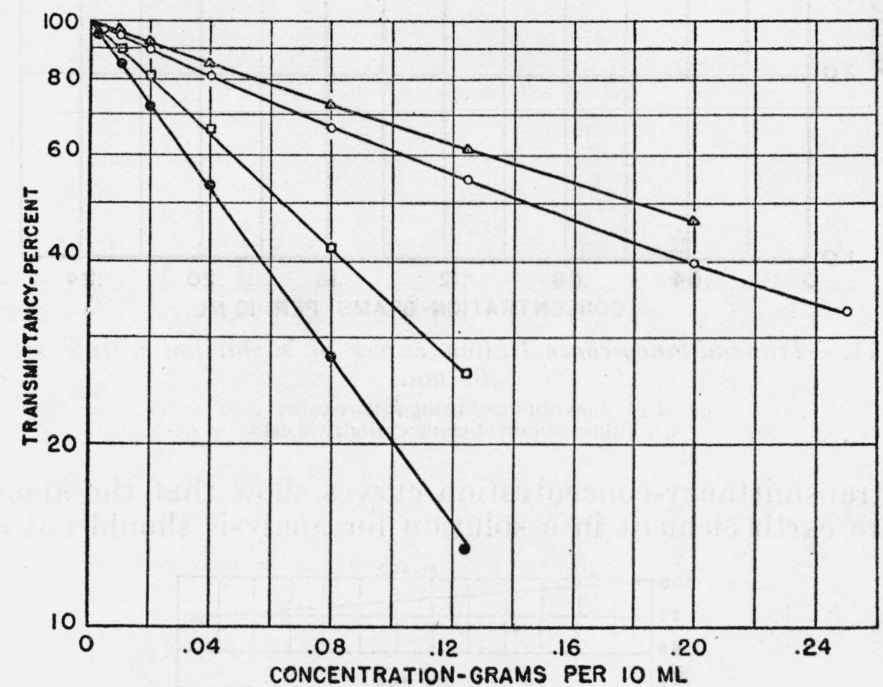

FrgURE 10.-Transmittancy-concentration curves of neodymium nitrate solutions a the wavelengths indicated.

A, Values obtained using square cells at $521 \mathrm{~m} \mu$.

, Values obtained using cylindrical cells at $521 \mathrm{~m} \mu$.

$\square$, Values obtained using cylindrical cells at $578 \mathrm{~m} \mu$.

, Values obtained using cylindrical cells at $798 \mathrm{~m} \mu$.

$\mathrm{m} \mu$ are shown in figure 9. The deviation from Beer's law in this case is evident. The results at $402 \mathrm{~m} \mu$ are shown in figure 12 on an enlarged linear scale. The effect of praseodymium at $521 \mathrm{~m} \mu$ is also indicated in this figure.

Transmittancy-concentration curves for amounts of neodymium ranging from 0.0025 to $0.25 \mathrm{~g}$ per $10 \mathrm{ml}$ are shown in figure 10 for the 521,578 , and $798 \mathrm{~m} \mu$ bands of neodymium nitrate. Beer's law holds closely for the 521,578 , and $798 \mathrm{~m} \mu$ bands in concentrations up to $0.10 \mathrm{~g}$ per $10 \mathrm{ml}$. There is a slight deviation from Beer's law for the band at $521 \mathrm{~m} \mu$ when the concentration increases to $0.25 \mathrm{~g}$ per $10 \mathrm{ml}$. The values at 402 and $446 \mathrm{~m} \mu$ are shown on an enlarged linear scale in figure 12 .

The transmittancy-concentration curves of samarium nitrate for the band at $402 \mathrm{~m} \mu$, for concentrations ranging from 0.025 to $0.25 \mathrm{~g}$ of 
samarium per $10 \mathrm{ml}$, is shown in figure 11. The transmittancies at 446 and $521 \mathrm{~m} \mu$ are shown in figure 12 .

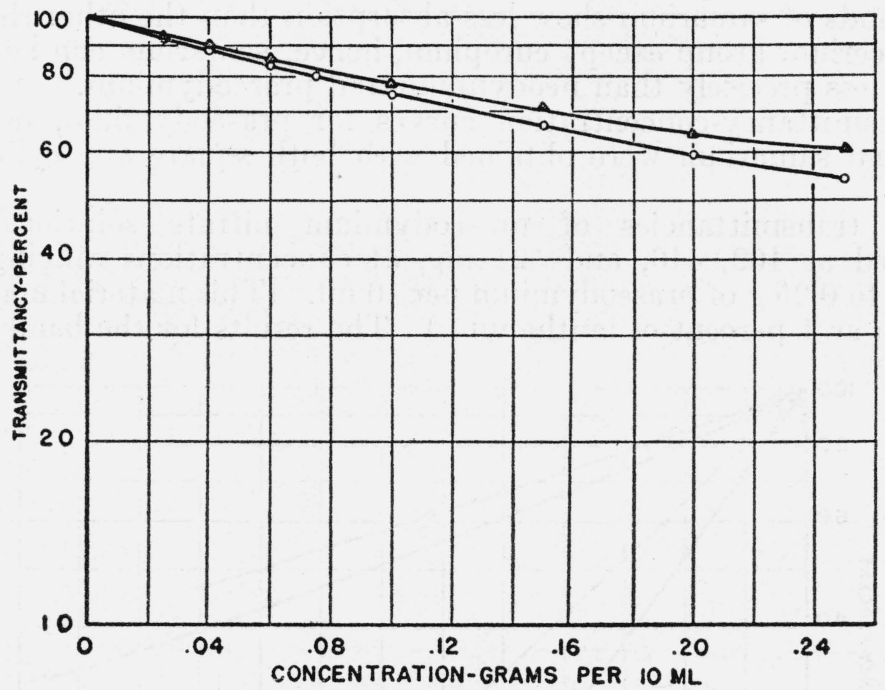

FIGURE 11.-Transmittancy-concentration curves of samarium nitrate solution at $402 m \mu$.

$\triangle$, Values obtained using square cells.

O, Values obtained using cylindrical cells.

The transmittancy-concentration curves show that the amount of each rare earth element in a solution for analysis should not exceed

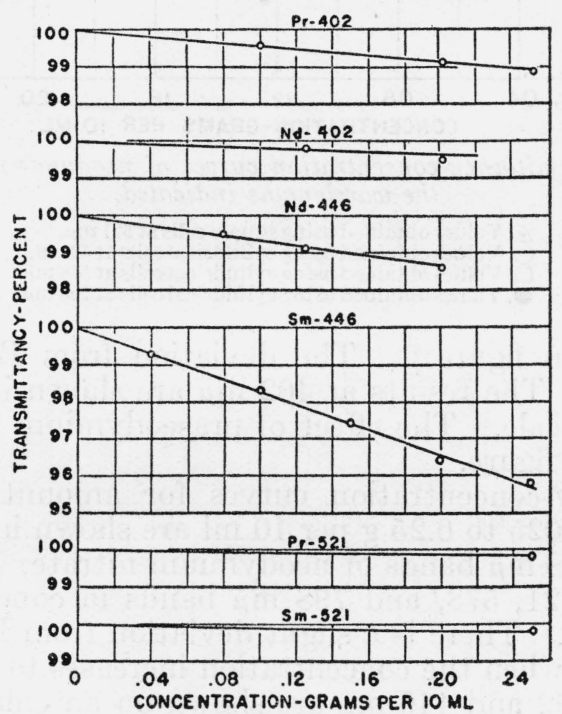

FIGURE 12.-Transmittancy-concentration curves of samarium, neodymium, and praseodymium nitrate solutions at the wavelengths indicated, using square cells.

approximately $0.20 \mathrm{~g}$ per $10 \mathrm{ml}$. This is about the maximum which can effectively be used, especially in the case of samarium, concentra- 
tions of which greater than $0.20 \mathrm{~g}$ per $10 \mathrm{ml}$ in the square cells change the transmittancy but slightly.

It will be noted from figure 12 that the presence of other rare earths will affect the transmittancy measurement of each element in question to a certain extent, and that the $446 \mathrm{~m} \mu$ band, which is used for the praseodymium determination, may be thus affected to the greatest extent. It is possible, however, to correct for the effect of these different elements, as will be shown later. The effect of lanthanum on small amounts of other rare earths in the cerium group was studied to see if any noticeable wavelength shift in bands was observed, as was reported by Quill, Selwood, and Hopkins. ${ }^{18}$ In the concentrations used, the shift of the bands, if present, was not sufficient to affect the results. Figure 8 shows that no noticeable shift in the wavelengths of minimum transmittancy of the bands was observed in a mixture of praseodymium, neodymium, and samarium.

\section{RESULTS OBTAINED}

A tabulation of the data obtained with a mixture of $0.075 \mathrm{~g}$ of samarium, $0.075 \mathrm{~g}$ of praseodymium, and $0.050 \mathrm{~g}$ of neodymium in a volume of $10 \mathrm{ml}$ in square cells is shown in table 1.

TABLE 1.-Illustration of the data obtained in the analysis of a solution of samarium, praseodymium, and neodymium

\begin{tabular}{|c|c|c|c|c|c|c|c|c|}
\hline 1 & 2 & 3 & 4 & 5 & 6 & 7 & $\varepsilon$ & 8 \\
\hline \multirow{2}{*}{ Element } & \multirow{2}{*}{$\begin{array}{l}\text { Wave- } \\
\text { length }\end{array}$} & \multirow{2}{*}{$\begin{array}{c}\text { Apparent } \\
\text { transmit- } \\
\text { taney }\end{array}$} & \multirow{2}{*}{$\begin{array}{l}\text { Transmit- } \\
\text { tancy of Pr } \\
\text { at wavelength } \\
\text { of col. 2, } \\
\text { excluding } 446\end{array}$} & \multirow{2}{*}{$\begin{array}{c}\text { Transmit- } \\
\text { tancy of Nd } \\
\text { at wavelength } \\
\text { of col. 2, } \\
\text { excluding } 521\end{array}$} & \multirow{2}{*}{$\begin{array}{l}\text { Transmit- } \\
\text { tancy of Sm } \\
\text { at wavelength } \\
\text { of col. 2, } \\
\text { excluding } 402\end{array}$} & \multirow{2}{*}{$\begin{array}{c}\text { Corrected } \\
\text { transmit- } \\
\text { tancy of } \\
\text { element listed } \\
\text { in col. } 1 \text {. Col. } \\
3 \div 4 \times 5 \times 6\end{array}$} & \multicolumn{2}{|c|}{$\begin{array}{c}\text { Amount of } \\
\text { element }\end{array}$} \\
\hline & & & & & & & Present & Found \\
\hline $\begin{array}{l}\mathrm{Sm} \\
\mathrm{Pr} \\
\mathrm{Nd}\end{array}$ & $\begin{array}{l}m \mu \\
402 \\
446 \\
521\end{array}$ & $\begin{array}{r}\text { Percent } \\
82.4 \\
53.6 \\
80.4\end{array}$ & $\begin{array}{r}\text { Percent } \\
99.7 \\
99.9\end{array}$ & $\begin{array}{r}\text { Percent } \\
99.8 \\
99.6\end{array}$ & $\begin{array}{r}\text { Percent } \\
98.5 \\
100.0\end{array}$ & $\begin{array}{r}\text { Percent } \\
82.8 \\
54.7 \\
80.5\end{array}$ & $\begin{array}{l}g \\
0.075 \\
.075 \\
.050\end{array}$ & $\begin{array}{l}\text { g } \\
0.075 \\
.076 \\
.052\end{array}$ \\
\hline
\end{tabular}

The transmittancy of the solution at 402,446 , and $521 \mathrm{~m} \mu$ is entered under column 3. From the transmittancy-concentration curves ${ }^{19}$ of samarium, praseodymium, and neodymium, as given in figures 11,9 , and 10 , it is noted that the apparent transmittancy given in column 3 corresponds to approximately $0.079 \mathrm{~g}$ of samarium, 0.080 $\mathrm{g}$ of praseodymium, and $0.054 \mathrm{~g}$ of neodymium per $10 \mathrm{ml}$. From figure 12 , which shows the transmittancy due to samarium, praseodymium, and neodymium at the various wavelengths, are obtained the values which are entered in columns 4,5 , and 6 . The transmittancy due to the element in question is then found by dividing the values in column 3 by the product of the values in columns 4,5 , and 6 . This value is entered in column 7 . From the transmittancy-concentration curves of figures 9,10 , and 11 , the concentrations of the various elements are found and listed in column 8.

\footnotetext{
${ }_{18}$ L. L. Quill, P. W. Selwood, and B. S. Hopkins, J. Am. Chem. Soc. 50, 2929 (1928).

${ }_{10}$ Since the transmittancy curves may vary importantly with slit-width and cell thickness, analysts should not use the data in this paper but should obtain their own standard curves.
} 
The data in table 2 illustrate the results obtained by the method when applied to mixtures of praseodymium, neodymium, and samarium.

TABLE 2.-Results obtained in the analysis of nitrate solutions containing varying amounts of $\mathrm{Pr}, \mathrm{Nd}$, and $\mathrm{Sm}$

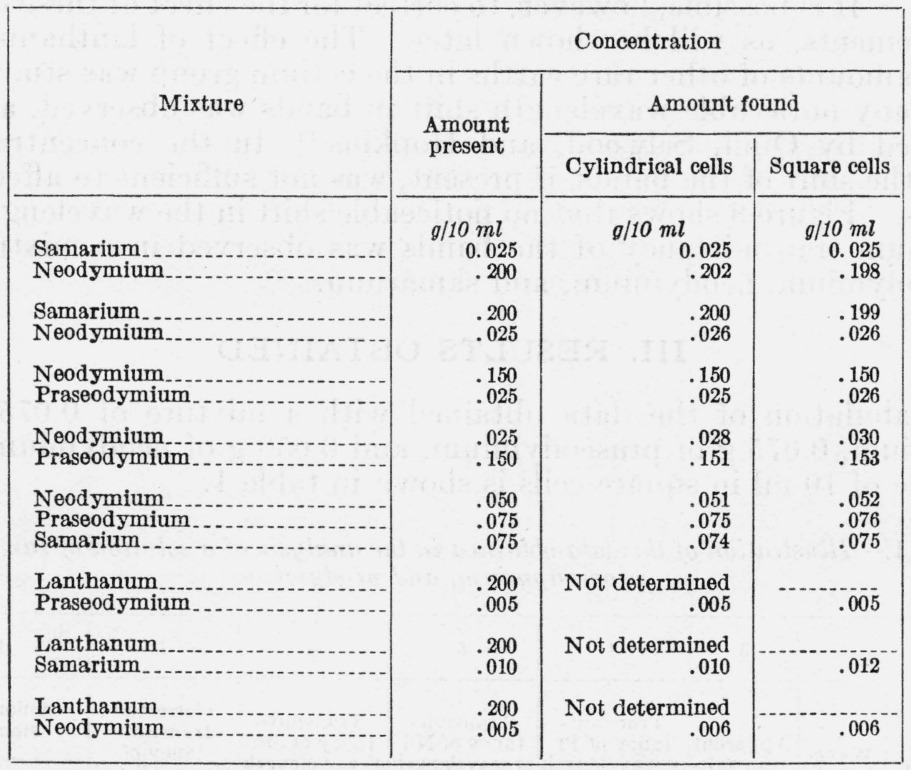

\section{DISCUSSION}

Lanthanum, cerium, and gadolinium all show the same type of general "absorption" (1-T) from 350 to $450 \mathrm{~m} \mu$. Extremely fine particles of dust, filter-paper fibers, and the like, which scatter the light at short wavelengths, may be the cause of this effect. It is recommended that all solutions used be centrifuged to remove as many particles as possible before transmittancy measurements are made.

The variation in reading transmittancy is seldom greater than \pm 0.2 unit on a scale of 100.0 units. The reproducibility of the wavelength setting is illustrated by the following data obtained for a solution of neodymium. Each reading represents a separate setting of the wavelength scale.

\begin{tabular}{|c|c|c|c|}
\hline $\begin{array}{c}\text { Wavelength } \\
\text { setting }\end{array}$ & \multicolumn{3}{|c|}{ Percent transmittancy } \\
\hline$m \mu$ & & & \\
729 & 76.8 & 76.7 & 76.6 \\
730 & 69.5 & 69.5 & 69.4 \\
731 & 62.7 & 62.9 & 62.9 \\
\hline
\end{tabular}


The data in table 2 show that deviations greater than $\pm 3 \mathrm{mg}$ are usually not obtained.

The presence of $2 \mathrm{mg}$ of praseodymium can be detected when the cylindrical cells are used and $1 \mathrm{mg}$ with the square cells. The sensitivity of the neodymium test depends on the band chosen; $0.5 \mathrm{mg}$ in $6 \mathrm{ml}$ can be detected at $798 \mathrm{~m} \mu$. When the $521 \mathrm{~m} \mu$ band is used, 1.5 $\mathrm{mg}$ of neodymium can be detected. Samarium does not give a very sensitive test, $3 \mathrm{mg}$ of it in a volume of $6 \mathrm{ml}$ being the smallest amount of this element which can be detected.

Europium, whose nitrate $S T$ curve is shown in figure 6, seriously affects the determination of samarium. However, the amount of europium can be determined by reduction and subsequent oxidation..$^{20}$ The transmittancy indicated for samarium could then be corrected for the interference of europium by means of a transmittancy-concentration curve of europium. Gadolinium, whose nitrate $S T$ curve is shown in figure 7 , has no bands from 350 to $1,000 \mathrm{~m} \mu$, but has a slight absorption similar to that of lanthanum near $350 \mathrm{~m} \mu$. The $S T$ curve of cerium nitrate is shown in figure 2 to indicate the effect of this element.

The applications of this spectrophotometric method in rare earth chemistry are many. The use of certain rare earths in the ceramic industry has introduced the problem of determining neodymium. As such mixtures are usually confined to members of the cerium group, a determination of neodymium can be readily made. The application of the method in following fractional crystallizations during the separation of rare earths is noteworthy. Impurities may be determined in so-called pure rare earth salts.

In a mineral analysis, the group consisting of lanthanum, cerium praseodymium, neodymium, samarium, europium, and gadolinium can be separated from the other group, but, as stated in the introduction, the separation is not sharp. However, by adding sodium sulfate until the neodymium absorption bands disappear it will be found that practically all of the cerium group is removed, contaminated somewhat by small amounts of some of the elements of the yttrium group. In the usual method of mineral analysis the cerium group is separated from the yttrium group, and cerium then determined by oxidation and titration. ${ }^{21}$ Cerium is reported as $\mathrm{Ce}_{2} \mathrm{O}_{3}$ and the remainder of the cerium group as mixed oxides of the form $\mathrm{R}_{2} \mathrm{O}_{3}$. The total summation of the analysis of the mineral is then somewhat in error, as praseodymium forms a higher oxide whose composition in mixtures is unknown (see footnote 17).

The following procedure is suggested for the analysis of the cerium group. The rare earths are separated first from other elements by some standard procedure. The cerium group is then separated from the yttrium group as the sodium double sulfates. Cerium is separated from the other elements of the cerium group ${ }^{22}$ and determined by oxidation and titration. As the lanthanum is determined by difference, it is necessary to treat the rare earth oxide mixture with hydrogen at $900^{\circ} \mathrm{C}$ to convert the black oxide of praseodymium to

\footnotetext{
${ }^{20}$ H. N. McCoy, J. Am. Chem. Soc. 58, 1577 (1936).

1 H. H. Willard and P. Young, J. Am. Chem. Soc. 50, 1379 (1928)

22 The author has found that this can be done quite satisfactorily by precipitating cerium as ceric hydroxide with zinc oxide. The bulk of the zinc is then separated from the rare earths by precipitating the rare earth hydroxides with a large excess of ammonia. The small amount of zine which remains with the rare earth is removed by means of hydrogen sulfide in $0.01 \mathrm{~N}$ sulfuric acid. The rare earths are then precipitated with oxalic acid and the oxalates ignited to the oxides. This procedure will be published in a subsequent paper.
} 
$\mathrm{Pr}_{2} \mathrm{O}_{3}$. The mixed oxides are then weighed. (Cerium is removed before the treatment with hydrogen, since it is very difficult to reduce all of the $\mathrm{CeO}_{2}$ to $\mathrm{Ce}_{2} \mathrm{O}_{3}$.) If necessary, europium is determined by the method of McCoy (see footnote 20), but it occurs in such small amounts in minerals that its presence can ordinarily be neglected. The mixed oxides, consisting chiefly of lanthanum, praseodymium, neodymium, and samarium, are converted to nitrates by dissolving in nitric acid and evaporating to dryness on a steam bath. The nitrates are dissolved in water and diluted to a known volume. The solution is now centrifuged to remove dust particles. Praseodymium, neodymium, and samarium are then determined by measuring their transmittancies at the proper wavelengths. The equivalent amounts of the several rare earths are calculated, as described in section III, from transmittancy-concentration curves constructed from transmittancy measurements on solutions prepared from salts of high purity. Lanthanum is obtained by difference. Gadolinium has no absorption in the visible region of the spectrum and will be included in the lanthanum value.

Washington, November 20, 1940. 